Palestine Exploration Quarterly

\title{
The Waters of Merom
}

\section{Canon Gover}

To cite this article: Canon Gover (1890) The Waters of Merom, Palestine Exploration Quarterly, 22:1, 50-54, DOI: 10.1179/peq.1890.22.1.50

To link to this article: http://dx.doi.org/10.1179/peq.1890.22.1.50

曲 Published online: 20 Nov 2013.

Submit your article to this journal 정

Џlll Article views: 3

Q View related articles $₫$ 
wall. But why not repair all the walls if there were workers enough ? Owing to the previous building of the enclosing wall of the Temple, Nehemiah's wall, as I draw it, is pushed so far west as to be at one part very little above the valley bed; and Mr. Birch ridicules this. But it is to be observed that even this part of the wall is at no lower level than the wall of Ophel, discovered by Warren. A wall in such a position was the best that the circumstances of the locality admitted of, and was better than none. It could not be reached unless the transverse wall were taken first. Its position could scarcely be weaker than that of the north-west wall of the city, which actually has higher ground outside. Mr. Birch's alternative is a wall carried from the south-west hill, round Siloam, to the eastern side of Ophel ; and this necessarily crosses the valley, and at a much lower level than the wall in my plan.

Finally, may I say that I have drawn a definite line of wall, and have correlated it at many parts of its course with points in Nehemiah's description; the argument is cumulative, and is not answered if one or two details be shown to be doubtful. Mr. Birch has not drawn his wall definitely, and could not make any wall going down to Siloam to tally with Nehemiah's descriptions. The Ophel wall actually discovered has no use on his theory, and apparently ought never to have been built. Further, comparing Neh. iii with Neh. xii, the processionists skip over a long line of wall repaired by the workers, and there is no way of disposing of it except by allowing the loop line as in my plan.

George St. Clair.

\section{THE WATERS OF MEROM.}

I. Grounds for supposing that the waters of Merom (Josh. xi, 5, 7) are not the Lake Semechonitis of Josephus and the Bahr el Haleh of the present day, and therefore that of this lake there is no mention in the Bible.

II. What was this "waters of Merom," and the locality of Joshua's victory over the northern tribes?

I. There appears to be no trace of the "waters of Merom" having been identified in ancient times with the Lake Semechonitis of Josephus; the Bahr el Hilleh of the Arab as far back at least as the Crusades. The district itself indeed in which this lake lies was known as the Ulatha in the days of Josephus. Ant. xv, 10; 3 .

Such identification, therefore, rests at best on slender inference, and is destitute of satisfactory authority. But the name having been once thus assigned (at what time it is difficult to trace) it has been taken as correct, and handed on by one writer after another without enquiry or question.

Now it struck me in closely examining the maps of Western Palestine with Stanley's account of Joshua's battle with the northern tribes, that there were difficulties in accepting his localisation which could not be got over. 
The following is a topographical description of the spot where he has placed the battle: "Owing to the triangular form of the lake a considerable space is left between the lake and the mountains at the lower end. This is more the case on the west than on the east, and the rolling plain thus formed is very fertile, and cultivated to the water's edge." Now, on such ground, chosen as Stanley says, "because along those level shores they could have full play for their force of chariots," the approach of Joshua with his men of war from the south as he crossed the Wâdies, and especially the Wâdy Hindâj, must have been visible for long distances, and from numerous points. He could hardly have fallen upon them suddenly; whilst had his attack with footmen been in this open plain, it could not have proved the decisive success which we know it was.

Again, the line of flight from the scene of defeat, had it been by the shores of Semechonitis, could hardly have been to Sidon the Great. The tremendous ravine of the Leittâni (Leontes), and the stern ridge of Kŭlảt es Shŭkif on its northern side, would forbid escape in that direction.

Again, too, it is objected that the word for water in the original would not be used for a lake, but the word for "sea," as of Tiberias $(a)$.

At all events the Septuagint constantly uses the expression "the water of "-always in the singular-to denote the stream running near some village, and named after it. Thus "the water of Megiddo,"

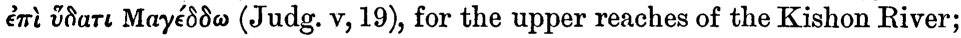
or again, "the water of Nimrim shall be desolate," "the water of Dimon shall be full of blood" (Isai. xv, 6 and 9), and so in other passages.

That is the Afon, Adwr, fó $\delta \omega \rho$, running near a town or village and borrowing its name from it, is what is meant by the expression "the water," $\tau \dot{o} v \tilde{v} \omega \rho$, and not a lake.

On such grounds then, it is unlikely that the Bahr el Holeh is meant by "the waters of Merom ;" and if so, there is no reference to this lake in the SS.

Indeed, the very existence of the name Merom here may be nothing more than a mistaken reading.

II. What then may more probably be the site of Joshua's third great final victory?

Now, in reference to the Septuagint we find that one of the kings to whom Jabin, King of Hazor, sends, is not Jobab, King of Madon, as it stands in the Authorised and Revised Versions (Josh. xi, 1); but

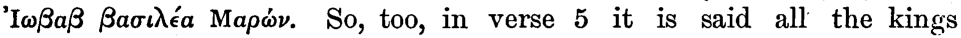

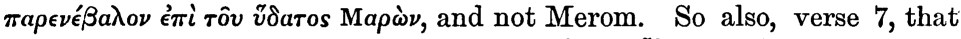

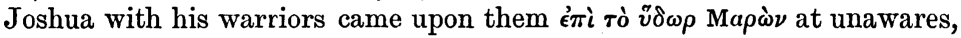
and fell upon them "in the mountainous country," $\epsilon \nu \tau \hat{\eta} \dot{o} \rho \epsilon \dot{\eta} \eta \hat{\eta}$.

Where, then, are we to look for this stream of Maron?

1 Smith's “ Bib. Dict.," s.v, Merom. 
Josephus informs us (Ant. v, $1, \S 18$ ) that "the kings pitched their camp at Beroth, a city in the Upper Galilee not far from Kadesh, itself also a place in Galilee."

Now, south of Kadesh runs a ravine with a perennial stream from the central watershed to the foot of the Bahr el Holeh, bearing at the present day in its downward course the names of Wâdy el Jish (Gischala), W. Fârah, W. 'Aûba, Tawahîn el 'Aưba, and lastly, Wâdy Hindâj.

Tu the north of this stream lay the towns of Hazor (over the Lake Senechonitis (Joseph. Ant. v, 5, §1), and then the head of all the kingdoms), Kadesh, Iron, (Josh. xix, 37), and perhaps, taking the reading of the Septuagint, Mâran ; for of these, Iron is probably the present Yârûn;

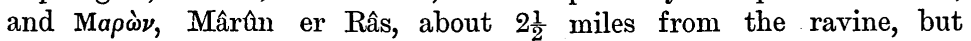
dependent on its stream for water; if, indeed, the addition, er Ras (b) does not point to the existence once of a Mâran lying on the lower ground, and perhaps coincident with Fârah.

Along this ravine, for the water's sake, lay, I imagine, the gathering hosts of the northern confederacy, somewhere about the part which bears now the name of Fârah.

Thus, too, they would have their store cities behind them, as they were organising their bands to sweep down against Israel across Esdraelon into central Palestine. But as they lay in fancied security near. to water, and in the crowded valley, by (c) a forced march of five days (Josephus, Ant. v, 1, §18) from Gilgal (Josephus and our versions, but not the Septuagint), Joshua and all the people of war fell upon them like a thunderbolt in the rocky ground (Septuagint) where their chariots would be useless.

Struck in the centre their army was broken asunder by the impetuous charge. Then the Israelites, facing westward and eastward on their flanks, would roll up their enemies in hopeless rout. Only at one point. perhaps was a stand made ; on the crest of the watershed at Kefr Birim, i.e., "the village of wells ; " surely the city of Beroth, i.e., "of wells" of Josephus. But the struggle was short. Led on, it may be by the mighty Caleb, the left wing of the Israelites drove their foes headlong down the tortuous valleys that at over twenty miles away open upon the road which, coming down from the Ladder of Tyre and north of Râs el Abiad, ran along the coast to the fords of the Leittâni, to Misrephothmaim (Zarephath) $(d)$ and Sidon the Great.

Eastward Joshua himself seems to have led the pursuit, perhaps between Kadesh and Hazor, cutting off the main body from their cities and driving them before him till he reached the valley of Mizpah eastward, under the roots of Hermon, whence the Hivite had descended to range himself under the banners of Jabin. Then, when the pursuit ceased with the slaughter of the last of the overtaken fugitives, Joshua turned back and took Hazor "and smote the king thereof," feebly' defending it with the remnant of his host "with the sword." "And they smote all the souls that were therein with the edge of the sword, utterly destroying them ; there was not any left to breathe, and he burnt 
Hazor with fire." And Hazor only. As it was done to Jericho in the south, so was it done to Hazor, the head of all those kingdoms in the north.

Such I suggest as the probable site of the battle, the course of the fugitives, and the final result.

Thus, it seems, may be best brought into unison the narratives of the Hebrew, the Septuagint, and Josephus.

\section{NOTES:}

(a) The Hebrew word $M e$ is not that commonly used for a large piece of standing water, but rather Yam, "a sea," which was even employed for so small a body of water as the artificial pond or tank in Solomon's Temple : Smith's "Dict. of Bible, s. v, Merom."

(b) As Râs el Akra on the hill and Akrabeh (Ekrebel, Jud. vii, 18) on the lower ground.

(c) This march could hardly have been from Gilgal in five days, for the distance, as the crow flies, is 75 miles.

(d) An objection to identifying Misrephothmaim with Zarephath might be, that it is named after Sidon in the description of the flight, whereas it would be reached on the way to it. Granting this, it would come in order as belonging to the eastward route of flight. Symmachus, says Eusebius, interprets it as Misraipoth of the sea. May it then be a place near the northern part of the Lake (Sea) Hôleh ?

WILLIAM Gover, Hon. Canon of Worcester.

\section{SAltLey Lodge, Worthing,} December, 1889.

\section{APPENDIX A.}

Merran (Merrom, Jerome).-Eusebius (whose Onomasticon with Jerome's translation I have had the opportunity of examining in his ample library through the kindness of my neighbour, Major Gaisford, of Offington) regards this village as the site of the battle. He describes it as twelve miles' distance from Sebaste (Samaria), and near Dothaim (the two cisterns?).

If so, the waters of Merom (Merran) must be the Brook Mochmur in the plain of Dothaim, south of the Carmel ridge, now known in its higher parts as the Wâdy es Selhab, and as the Nahr el Mefjir at its debouchement into the Mediterranean. But this point is fifty miles distance from Hazor and Kedesh, and such localisation can in no way be made to cohere with the precise narrative in Joshua of the lines of flight. 
MErron. - So much could not be said against a conjecture that should place the site of the battle near Meiron, about three miles south of EI Jish (Gischala), with its wâdy running from west to east till it joins the larger Wâdy et Tawahin near the western foot of the hill on which Safed stands. Yet even so, if this were the site the western line of flight would surely be the shorter route south (not north) of the Ladder of Tyre and the Râs el Nâkûrah, to the friendly cities of Accho, Achsaph, and Achzib, while the eastward would seek the fords of the Jordan below Lake Huleh.

The examination, therefore, of both these alternatives tends to confirm the correctness of the supposition which places the site of the battle near Maroon and Kefr Birîm.

\section{APPENDIX B.}

Eusebius' Onomasticon ; Jerome's Liber de situ, \&c., Joshua:

Eusebii Hieronymi Opera, Tom. III, p. 243. Editio Vallarsii, Veronæ MDCCXXXv.

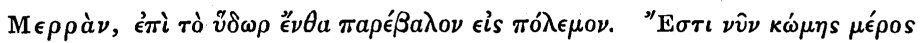

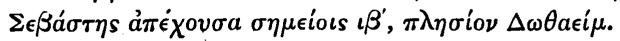

Merrom.-Aquæ ad quas exercitu præparato castra sunt posita. Est autem nunc vicus Merrus nomine in duodecimo milliario urbis Sebastæ juxta Dothaim.

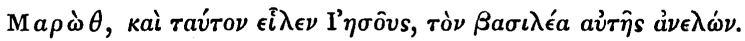

Marom:-Et hanc cepit Jesus, rege illius interfecto. (Posita est et supra Marrus.)

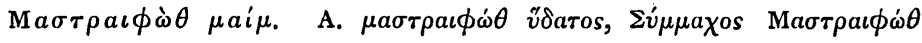
$\theta a \lambda a ́ \sigma \sigma \eta s$.

Massephoth maim : pro quo Aquila Massephoth aquæe; Symmachus, Massephoth maris, interpretati sunt.

\section{NOTE ON GREEK INSCRIPTION.}

Allow me to suggest that the inscription No. 4 on Plate at p. 183 of the last (October) Quarterly Statement should be read as "the Memorial (THC DOU $\lambda H C$ COUZANNAC) of the servant [minister] Susanna, not Anna, as rendered in the note, p. 179.

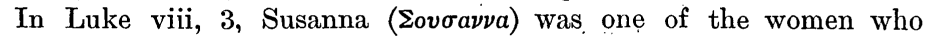

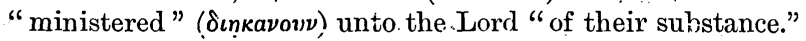

Have we here a Hebrew (Christian) memorial of mosaic, wrought in 